\title{
Article \\ Carbon Losses from Decomposing Windrowed Sitka Spruce Woody Debris Over a 16-Year Chronosequence
}

\author{
Brian Tobin ${ }^{1,2, *(\mathbb{D})}$, Giovanni Pastore ${ }^{3}$ and Maarten Nieuwenhuis ${ }^{1}$ (D) \\ 1 UCD Forestry, School of Agriculture and Food Science, University College Dublin, Belfield, Dublin 4, Ireland; \\ maarten.nieuwenhuis@ucd.ie \\ 2 UCD Earth Institute, University College Dublin, Belfield, Dublin 4, Ireland \\ 3 Soil Ecology, University of Bayreuth, Dr.-Hans-Frisch-Straße 1-3, D 95448 Bayreuth, Germany; \\ giovanni.pastore@uni-bayreuth.de \\ * Correspondence: brian.tobin@ucd.ie; Tel.: +35-3-1716-7352
}

Citation: Tobin, B.; Pastore, G.;

Nieuwenhuis, M. Carbon Losses from Decomposing Windrowed Sitka Spruce Woody Debris Over a 16-Year Chronosequence. Forests 2021, 12 , 244. https://doi.org/10.3390/ f12020244

Academic Editor: Timo Domisch

Received: 1 January 2021

Accepted: 17 February 2021

Published: 20 February 2021

Publisher's Note: MDPI stays neutral with regard to jurisdictional claims in published maps and institutional affiliations.

Copyright: (c) 2021 by the authors. Licensee MDPI, Basel, Switzerland. This article is an open access article distributed under the terms and conditions of the Creative Commons Attribution (CC BY) license (https:// creativecommons.org/licenses/by/ $4.0 /)$.

\begin{abstract}
Meeting the reporting requirements of the Kyoto Protocol has focused attention on the potential of forests in sustainably sequestering carbon $(C)$ to mitigate the effects of rising levels of atmospheric $\mathrm{CO}_{2}$. Much uncertainty remains concerning the ultimate effect of management on such sequestration effects. The management of woody debris (WD) and other deadwood stocks is an example of a management intervention with the scope of affecting the source-sink dynamics of forest $C$. Windrowing is the most commonly employed approach to the management of post-harvest WD. This study investigated the quantities of windrowed deadwood C across a chronosequence of reforested commercial Sitka spruce stands in Ireland and how its decomposition rate affected its contribution to forest $C$ sequestration. The $C$ stocks in windrowed WD ranged from 25 to $8 \mathrm{t} \mathrm{Cha}^{-1}$ at the 4- and 16-year-old stands, respectively. Losses due to the decomposition of these stocks ranged from $5.15 \mathrm{t} \mathrm{C} \mathrm{ha}^{-1} \mathrm{yr}^{-1}$ at the youngest site (4 years old) to $0.68 \mathrm{t} \mathrm{C} \mathrm{ha}^{-1} \mathrm{yr}^{-1}$ at the oldest site (16 years old). Using a visual decay-class categorization of WD components and an assessment of wood density, decay rate constants were estimated for logs, branches, and stumps (the main WD constituents of windrows) as $0.037,0.038$, and 0.044 , respectively. These results, derived from stand stock evaluations, were placed into context with data previously published from the same chronosequence that characterized the day-to-day fluxes to or from this pool. This comparison indicated that though only a very small quantity of $C$ was lost in dissolved leachate form, the most significant pathway for loss was respiratory and ranged from 16 to $8 \mathrm{tC} \mathrm{ha}^{-1} \mathrm{yr}^{-1}$ at the 9 - and 16-year-old sites. These estimates were many times greater in extent than estimates made using a density-loss approach, the difference indicating that fragmentation and weathering play a large role in woody decomposition in intensively managed forests.
\end{abstract}

Keywords: coarse woody debris (CWD); woody decomposition; density loss; decay rate; carbon stock; single exponential model

\section{Introduction}

Forest ecosystems are severely affected by both planned and unplanned disturbance events, which include management interventions as well as biotic and abiotic factors. Climate change is predicted to further increase the likelihood and severity of such disturbances as it might promote significant changes in the above- and belowground organic matter allocation and flux within forest ecosystems. Woody debris (WD), consisting of timber and dead plant material residues left on site after harvesting or thinning operations, is a significant structural element of old-growth forest ecosystems [1-3], as it is a major component of the habitat of many plants, fungi, animals, and microbes. Following clearcut harvests, both coarse and fine woody debris are often arranged in uneven piled rows of residual material called "windrows" to partially clear the forest floor to facilitate planting and establishment work for the subsequent rotations. This management practice is 
common in commercial coniferous stands in Ireland (e.g., Figure 1), but is also frequently practiced following clearfells particularly in North America, Scandinavia, New Zealand and the UK. An ability to calculate the input to and output from WD at different stages of decay would enhance the capacity of forest management to increase the ecosystem multifunctionality offered by dead wood habitats and the biodiversity they support $[4,5]$. Forest managers in Ireland are currently concerned about the retention of adequate amounts of coarse woody debris (CWD) on sites after harvesting, because nutrient dynamics are influenced by debris abundance and the growth of residual and re-establishing vegetation. Consequently, the long-term impacts of intensive utilization (e.g., whole-tree or stump harvesting) and reductions in rotation length on windrowed CWD may greatly influence the overall nutrient capital and organic matter accumulation [6-8]. Furthermore, CWD has often been overlooked because of its spatial variation, slow decomposition, and the difficulty in attaining the necessary knowledge of forest management history $[8,9]$. Indeed, determining the rate of CWD production requires long periods of observation over large areas $[10,11]$. However, WD is recognized as an important habitat component in the nutrient and organic matter dynamics of managed European forests, although there is only a general understanding of its structural and functional role because of the difficulty in its quantification and qualification, and its high degree of variability [12]. The quantity of wood residues remaining on a harvested site can contain a considerable nutrient capital [8], which is added to that which enters the system as throughfall precipitation. If nutrients are added faster than they are leached out by rain, the result is positive nutrient storage $[13,14]$. The functional importance of WD is influenced by the volume that is produced, its degree of decay, size, spatial arrangement, orientation, and the species $[2,15,16]$. Nakamura and Swanson [17] pointed out that the physical distribution of WD on sites could even influence stream geomorphology, sediment storage, forest floor topography, and microclimate conditions on a local scale.

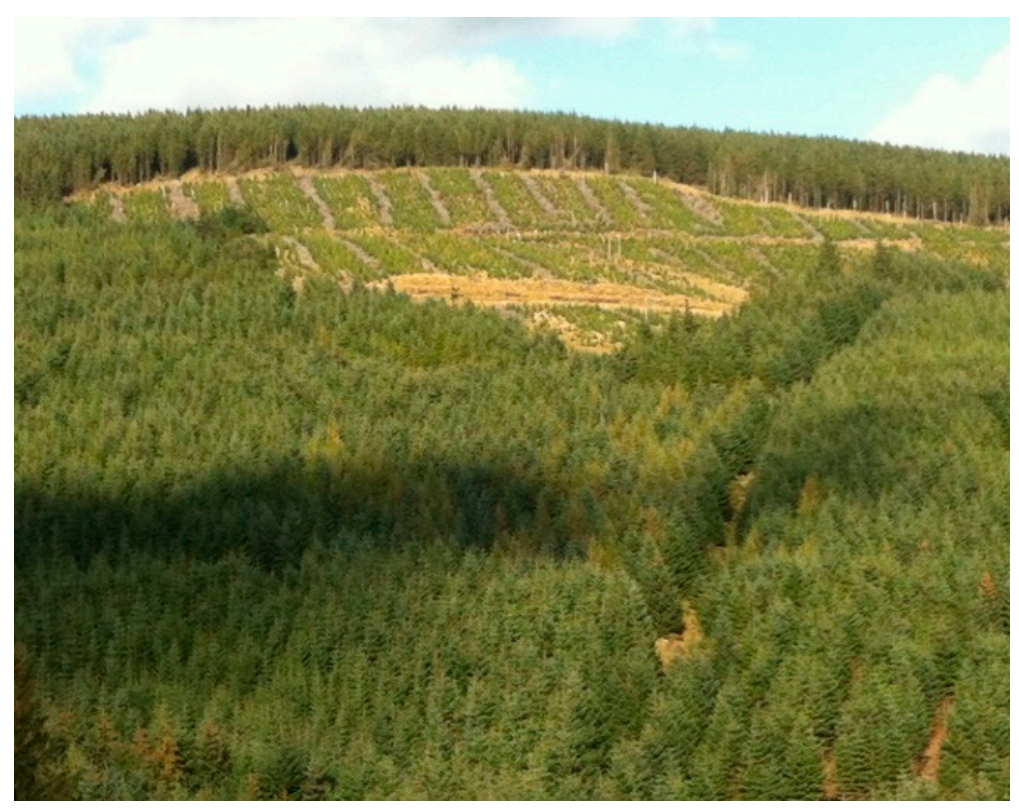

Figure 1. Cont. 


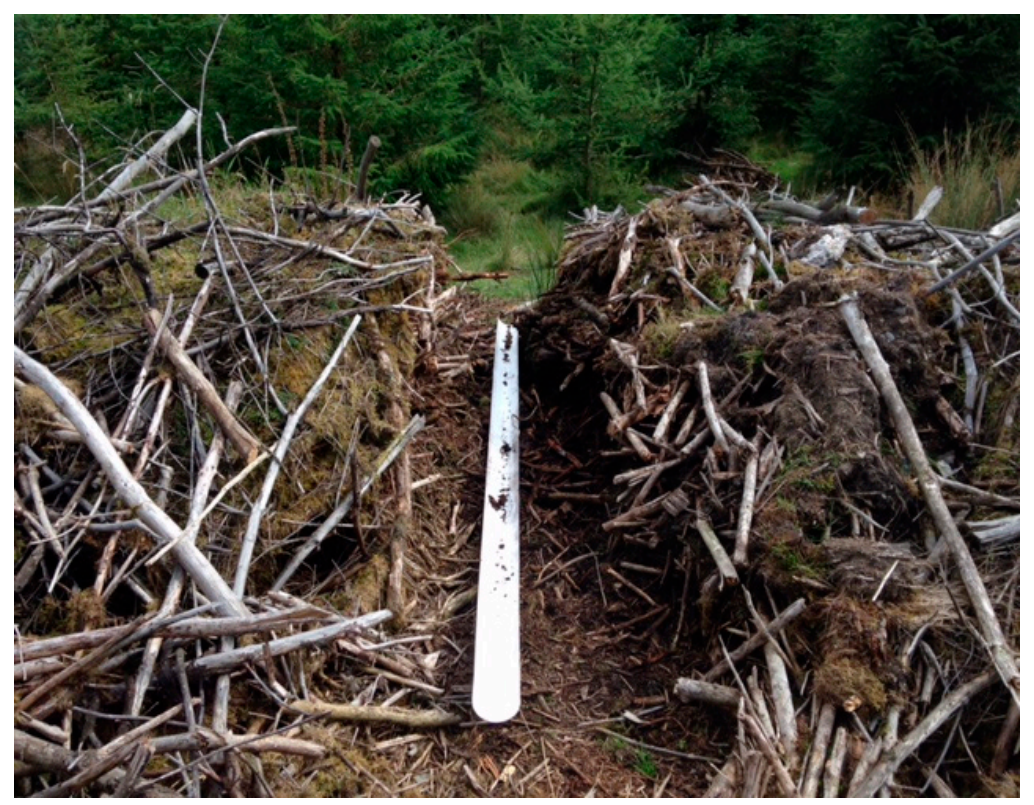

Figure 1. Windrowed woody debris (WD) visible on the clearfelled and reforested stand on the brow of the hill at Ballinastoe forest (top). Sampling involved cutting a $50 \mathrm{~cm}$-wide band across a windrow directly above where lysimeters had been inserted a year previously (bottom). The debris removed was sorted into various categories and decay classes.

Downed WD also represents an important carbon (C) store, constituting between 1 and $45 \%$ of the aboveground biomass, and has been described as a short-term sink and a long-term source of nutrients in forest ecosystems [18-20]. Consequently, as WD C stores are expected to increase significantly in some regions (temperate and boreal forests) due to higher frequency of disturbance events stimulated by warming climates [21], increased knowledge of how WD decomposition influences the forest $C$ balance is necessary. In general terms, the decomposition rate (k) of WD decreases with increasing size, which means that smaller sizes tend to decompose faster than larger pieces, resulting in shorter turnover times of smaller material than those of larger pieces [21]. However, some exceptions to this general trend do occur [16,22,23].

The decomposition of WD involves several different processes: microbial colonization, weathering, leaching, and fragmentation. Microbial decomposition results from the colonization of WD by a variety of fungi, protozoa and bacteria leading to mainly respiratory losses to the atmosphere [21]. Weathering is caused by gravity or water breaking the WD into smaller pieces, which expose more surface area for microbial colonization [16]. Leaching losses occur through dissolution in percolating water [24]. Fragmentation refers to the reduction of volume by environmental conditions (both physical and chemical) and biological mechanisms $[15,23]$. For example, saprotrophic fungi are understood to play a key role as biotic agents of wood decomposition. Brown and white rot fungi decay both lignocellulose and cellulose, while soft-rot fungi target the decay of cellulose [25]. Also, invertebrates rely on WD as a food source: the digested WD decays more rapidly due to the increased surface area to volume ratio [15]. Birds and mammals increase fragmentation by foraging for insects in the WD and likewise plant roots that burrow through woody material in search of nutrients [26]. Studies not considering the fragmentation process would underestimate $k$, and therefore overestimate site-level $C$ retention $[27,28]$. In addition, national greenhouse gas inventories require detailed information on $C$ stored in dead woody biomass and its relationship with different decay categories. Thus, information on residence times of WD across the whole spectrum of its decay stages is required to reliably estimate and model $\mathrm{C}$ accumulation, nutrient cycling dynamics and the impact of management on both $[21,23]$. 
The primary aim of this study was to investigate the contributions of windrowed WD to ecosystem $C$ stocks and losses in a typical Sitka spruce (Picea sitchensis (Bong.) Carr.)dominated Irish forest type and, in particular:

1. to quantify the change in WD stocks on a time series of windrowed sites;

2. to measure the decomposition rate and half-lives of logs, branches and stumps within those windrows;

3. to investigate the effect of the stage of decomposition on annual C losses; and

4. to compare WD decomposition between open and closed stands.

\section{Materials and Methods}

\subsection{Field Measurement of Woody Debris}

A chronosequence approach allowed a characterization of changes in WD quantity (volume) and quality (density) by sampling comparable reforested sites with different known times since disturbance. Five sampling plots were located in each of five chronosequence sites. The same sampling sites were also used by Pastore et al. [29], who provided a more detailed site description, to measure losses of $C$ from decomposing WD via respiration to the atmosphere and as dissolved losses leached to the soil and water table. In this study, the same sampling locations were used to assess the $C$ stocks in windrowed harvest debris at different-aged forest sites. Chronosequence sites were located in reforested stands in a commercially managed forest property, Ballinastoe in northeast Wicklow, Ireland. Five sites, labelled A to E, shared similar soil types, local climatic conditions and stand management, and were within $4 \mathrm{~km}$ of one another. They differed from one another in stand age (which ranged from 4 to 16 years since clearfell), vegetation cover and canopy height. Five sampling plots $(30 \times 20 \mathrm{~m})$ were randomly located in representative areas of each site and included a 20-m length of windrow. Stand and windrow characteristics are given in Table 1.

Table 1. Stand and windrow characteristics across the chronosequence of sampling sites (A to E) at Ballinastoe forest. Sample sites were classified according to woody debris (WD) age, i.e., the number of years since the clearfell that ended the previous rotation. The width and height of windrows included in sampling plots were measured every $1 \mathrm{~m}$ and a mean calculated.

\begin{tabular}{ccccccc}
\hline $\begin{array}{c}\text { Sample } \\
\text { Site }\end{array}$ & $\begin{array}{c}\text { WD Age } \\
\text { (years) }\end{array}$ & $\begin{array}{c}\text { Stand } \\
\text { Density } \\
\text { (stems h }\end{array}$-1) & $\begin{array}{c}\text { Stand } \\
\text { Mean } \\
\text { DBH (cm) }\end{array}$ & $\begin{array}{c}\text { Stand Mean } \\
\text { Height (m) }\end{array}$ & $\begin{array}{c}\text { Windrow } \\
\text { Width (m) }\end{array}$ & $\begin{array}{c}\text { Windrow } \\
\text { Height } \\
(\mathbf{m})\end{array}$ \\
\hline Site A & 3 & 2040 & 1.03 & 0.89 & 2.06 & 1.20 \\
Site B & 6 & 1980 & 2.20 & 2.24 & 1.96 & 1.35 \\
Site C & 8 & 1850 & 3.06 & 3.94 & 2.36 & 1.60 \\
Site D & 13 & 1575 & 11.76 & 4.67 & 1.71 & 1.04 \\
Site E & 15 & 1740 & 12.97 & 7.87 & 1.89 & 0.40 \\
\hline
\end{tabular}

Every effort was made to ensure the equivalency of the chronosequence stages. Management company records showed that the windrows on sites A and B were formed 2 years after clearfell using tracked excavators, and both in the spring period. Though records were not available for the remaining sites, similar management was assumed. The management company stated that the stand management objectives $(4.9 \mathrm{~m}$ and $3 \mathrm{~m}$ sawlog and pulpwood assortments) and the harvest system (cut-to-length, felled and processed by a mechanical harvester and extracted by forwarder) had been similar for all 5 chronosequence stands. No records were available for the stands which were clearfelled but they had reached full rotation ( $>30$ years).

A $50 \mathrm{~cm}$-wide band was marked across each windrow (centered directly above each lysimeter) and a chainsaw used to cut through all material on either side as far as the soil surface (Figure 1). All debris was removed from these bands and sorted into the following categories: $\operatorname{logs}$ ( $>7 \mathrm{~cm}$ minimum diameter); branches (diameter $<7$ and $>1 \mathrm{~cm}$ ); stumps (refers to remaining portion of trunk attached to roots); roots; bark; litter (including needles 
and twigs, $<1 \mathrm{~cm}$ diameter); and moss (including herbaceous plants often in dense mats on bark or windrow surfaces). Periodically, soil was found to have been included in windrows, though only episodically and as a very minor component.

A $7 \mathrm{~cm}$ minimum diameter for logs was chosen as it coincides with the commercial minimum "timber size" used in Irish forest management (see Olajuyigbe et al. [30]). The age of the material was determined based on the management history of the chronosequence site (i.e., age ranged from 4 to 16 years after the clearfell harvest event). Logs, branches and roots were categorized into decay classes (DCs) based on visual (see Arthur and Fahey [31] and physical characteristics linked to the degree of decomposition (Table 2). A five-class system is most commonly used [32] and this had been previously adapted to local conditions. The fresh weights of all material in each category were recorded in the field using a digital hanging scale (Intercomp CS200TM, Medina, MN, USA). A total of twenty-five windrows were sampled.

Table 2. A five-category decay class system (described in Tobin et al. [11] and Olajuyigbe et al. [30]) was used to assess the degree of decomposition of windrowed woody debris (logs, branches and stumps).

\begin{tabular}{cr}
\hline Decay Class & Characterization \\
\hline 0 & Freshly felled/cut material. \\
1 & $\begin{array}{r}\text { Material surface whole and hard, with bark intact, some signs of decay in places. } \\
\text { Sapwood soft in patches, fragmentation evident, bark } \geq 50 \% \text {, all branch knots } \\
\text { flush with surface or can be seen. }\end{array}$ \\
3 & Large blocky pieces missing. Outline frame deformed. Portions of sapwood \\
& missing. Branch knots prominent. Little bark present.
\end{tabular}

\subsection{Basic Density Determination}

Three random subsamples (for each DC represented) of the log, branch and stump samples were collected at each of the five sampling plots at all five chronosequence stages. The wet weight of each subsample was measured and the volume of individual pieces of wood was determined gravimetrically using the water displacement method described by Olesen [33], where the volume of subsamples was recorded as the mass of displaced water [34]. To reduce water absorption and minimize sample disintegration, highly decomposed material (e.g., samples categorized as DCs 3 and 4) was wrapped in cling film. Subsequently, all subsamples were oven-dried at $70{ }^{\circ} \mathrm{C}$ to constant mass. Basic density was calculated as the ratio of dry mass to fresh volume [23] and mean densities were calculated for each category per DC. A percentage loss from the original fresh density for each category at each plot was derived. Plot stem, branch and stump WD categories were then averaged and scaled to stand level $\left(\mathrm{ha}^{-1}\right)$, resulting in the final stand volume and mass estimates. For each category and decay class, volume was converted to $C$ stock per hectare using Equation (1).

$$
C=v \times d \times 0.47
$$

where $v$ is volume, $\mathrm{d}$ the basic density and 0.47 the rounded $C$ conversion factor calculated by Olajuyigbe et al. [30]. Carbon fraction has previously been found not to vary significantly with WD age [11,35].

\subsection{Decomposition Rate}

WD decomposition strongly influences nutrient cycling within forest ecosystems. Therefore, an accurate estimate of decomposition rate is critical to a more complete understanding of biogeochemical cycling. The decay rate constant $k$, of forest WD was derived using a single exponential model (Equation (2)).

$$
Y_{t}=Y_{0} e^{-k t}
$$


where $Y_{t}\left(\mathrm{~g} \mathrm{~cm}^{-3}\right)$ is wood mass at time $t, Y_{0}\left(\mathrm{~g} \mathrm{~cm}^{-3}\right)$ the initial mass, and $k\left(\mathrm{~g} \mathrm{~cm}^{-3} \mathrm{yr}^{-1}\right)$ the decomposition rate constant. The single exponential model treats decayed wood as a homogeneous substrate. The decay rate constant $(k)$ can be also used to estimate the time required to decompose half a quantity of wood, $(0.50 t=0.693 / k)$, known also as turnover time.

\subsection{Data Analysis and Statistics}

Statistical analysis was performed using Sigma Plot (version 12.0, Systat Software -Inc., San Jose, USA). All data sets in this study were tested for normality (Shapiro-Wilk) as well as for equal variance. To detect significant differences between WD stocks and DC densities, a combination of one-way analysis of variance (ANOVA) and post-hoc analysis based on Tukey's test was used. The Pearson product moment coefficients were calculated to assess the correlation between variables. Statistical significance was established at the $5 \%$ level, unless otherwise stated. A single exponential decay curve was used to describe density decay rates for each CWD type.

\section{Results}

\subsection{Plot Inventory, C Stocks, and C Losses Comparisons}

Based on field observations, $C$ stocks of WD pieces gradually increased over the younger stages (sites $\mathrm{A}$ to $\mathrm{C}$ ) before declining steadily at the older stands (with a statistical difference, $p=0.030, p=0.022$, and $p=0.012$ respectively for logs, branches, and stumps between sites $B$ and E). Post-hoc comparisons indicated that WD stocks did not differ significantly at the 0.05 level across sites A, B, and C. C stocks were initially divided by categories found within the windrows (Figure 2a) and subsequently between three pools, namely logs, branches, and stumps according to DCs (Figure $2 b$ ). The greatest $C$ stock was that of branches, ranging from $3.29 \mathrm{tC} \mathrm{h}^{-1}$ at the oldest site (16 years old) to $20.34 \mathrm{t} \mathrm{C} \mathrm{h}^{-1}$ at the intermediate stand ( 7 years old). The other two WD stocks ranged between 4.10 and $14.93 \mathrm{t} \mathrm{Ch}^{-1}$ for logs and from 0.18 to $1.46 \mathrm{t} \mathrm{C} \mathrm{h}^{-1}$ for stumps. From the percentage loss in WD density, the amount of initial stock that each WD pool had at each chronosequence site was computed. The difference between each of these quantities and the current (time of sampling) decayed stocks made it possible to calculate stock losses due to decay at each forest site (Table 3). These losses ranged from $0.68 \mathrm{tC} \mathrm{h}^{-1} \mathrm{yr}^{-1}$ at the oldest site (16 years old) to $5.15 \mathrm{t} \mathrm{C} \mathrm{h}^{-1} \mathrm{yr}^{-1}$ at the youngest site (4 years old).

Table 3. Current WD stocks $\left(\mathrm{tC} \mathrm{ha}^{-1}\right)$ and losses $\left(\mathrm{t} \mathrm{Cha}^{-1}\right)$ along the 16-year chronosequence.

\begin{tabular}{|c|c|c|c|c|c|}
\hline WD Pools & Site A & Site B & Site C & Site D & Site $\mathrm{E}$ \\
\hline \multicolumn{6}{|l|}{ Stocks } \\
\hline $\operatorname{Logs}\left(\mathrm{t} C \mathrm{ha}^{-1}\right)$ & 8.30 & 14.93 & 3.19 & 4.10 & 4.83 \\
\hline Branches (t C ha $\left.{ }^{-1}\right)$ & 15.12 & 20.34 & 20.17 & 5.89 & 3.29 \\
\hline Stumps ( $\left.\mathrm{C} \mathrm{ha}^{-1}\right)$ & 1.14 & 0.92 & 1.46 & - & 0.18 \\
\hline Total $\left(\mathrm{t} \mathrm{C} \mathrm{ha}{ }^{-1}\right)$ & 24.56 & 36.19 & 24.82 & 9.99 & 8.30 \\
\hline \multicolumn{6}{|l|}{ Losses } \\
\hline $\operatorname{Logs}\left(\mathrm{t} C \mathrm{ha}^{-1}\right)$ & 6.77 & 4.53 & 1.25 & 4.18 & 3.35 \\
\hline Branches (t C ha $\left.{ }^{-1}\right)$ & 13.77 & 16.49 & 34.10 & 11.73 & 7.18 \\
\hline Stumps ( $\left.\mathrm{C} \mathrm{ha}^{-1}\right)$ & 0.08 & 0.13 & 2.69 & - & 0.42 \\
\hline Total loss $\left(\mathrm{t} C \mathrm{ha}^{-1}\right)$ & 20.62 & 21.15 & 38.04 & 15.91 & 10.95 \\
\hline$\%$ loss of $\mathrm{C}$ & 4.87 & 8.43 & 14.60 & 15.73 & 14.35 \\
\hline Debris age (years since harvest) & 4 & 7 & 9 & 14 & 16 \\
\hline Annual loss $\left(\mathrm{t} C \mathrm{ha}^{-1} \mathrm{yr}^{-1}\right)$ & 5.15 & 3.02 & 4.22 & 1.13 & 0.68 \\
\hline
\end{tabular}




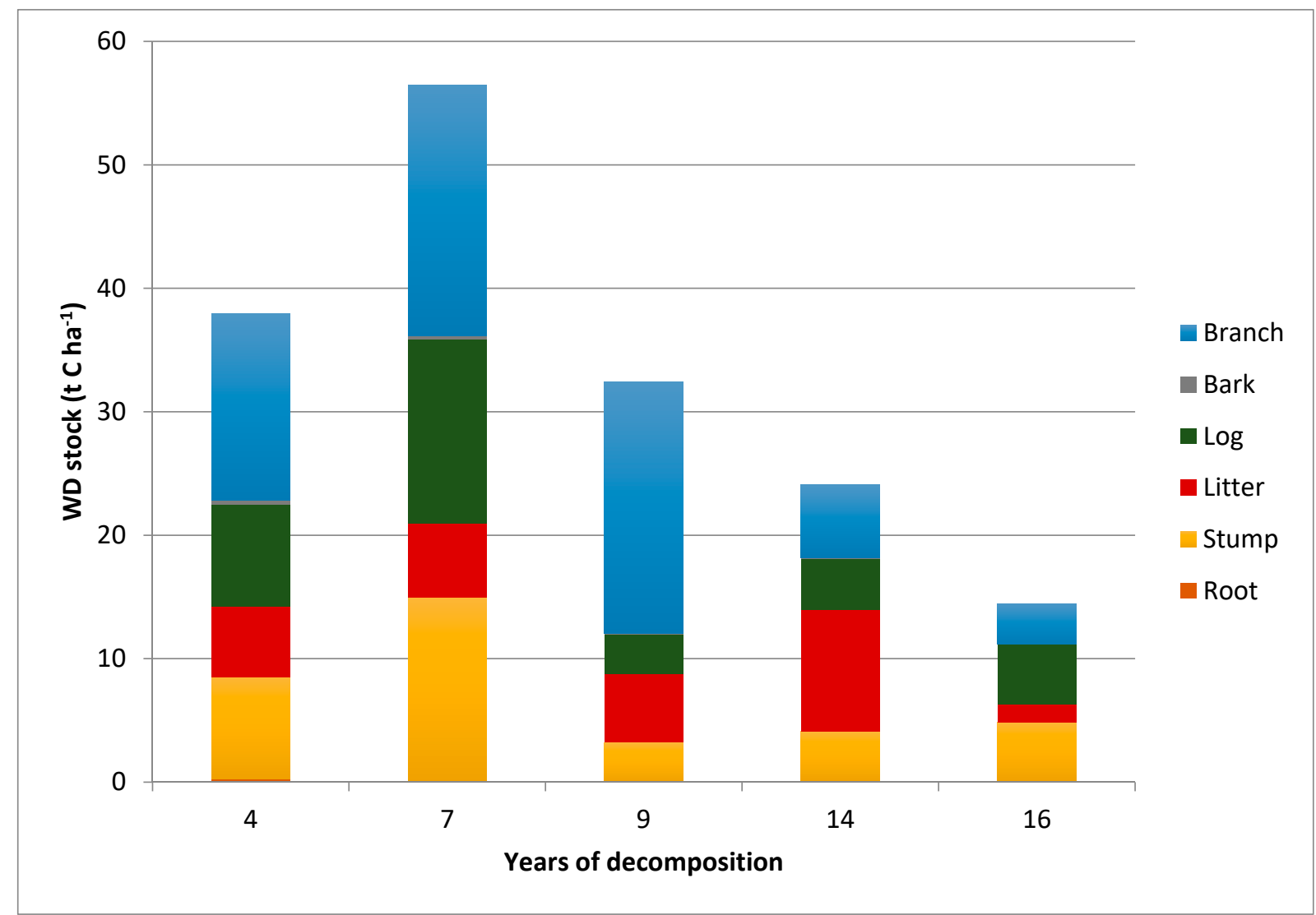

(a)

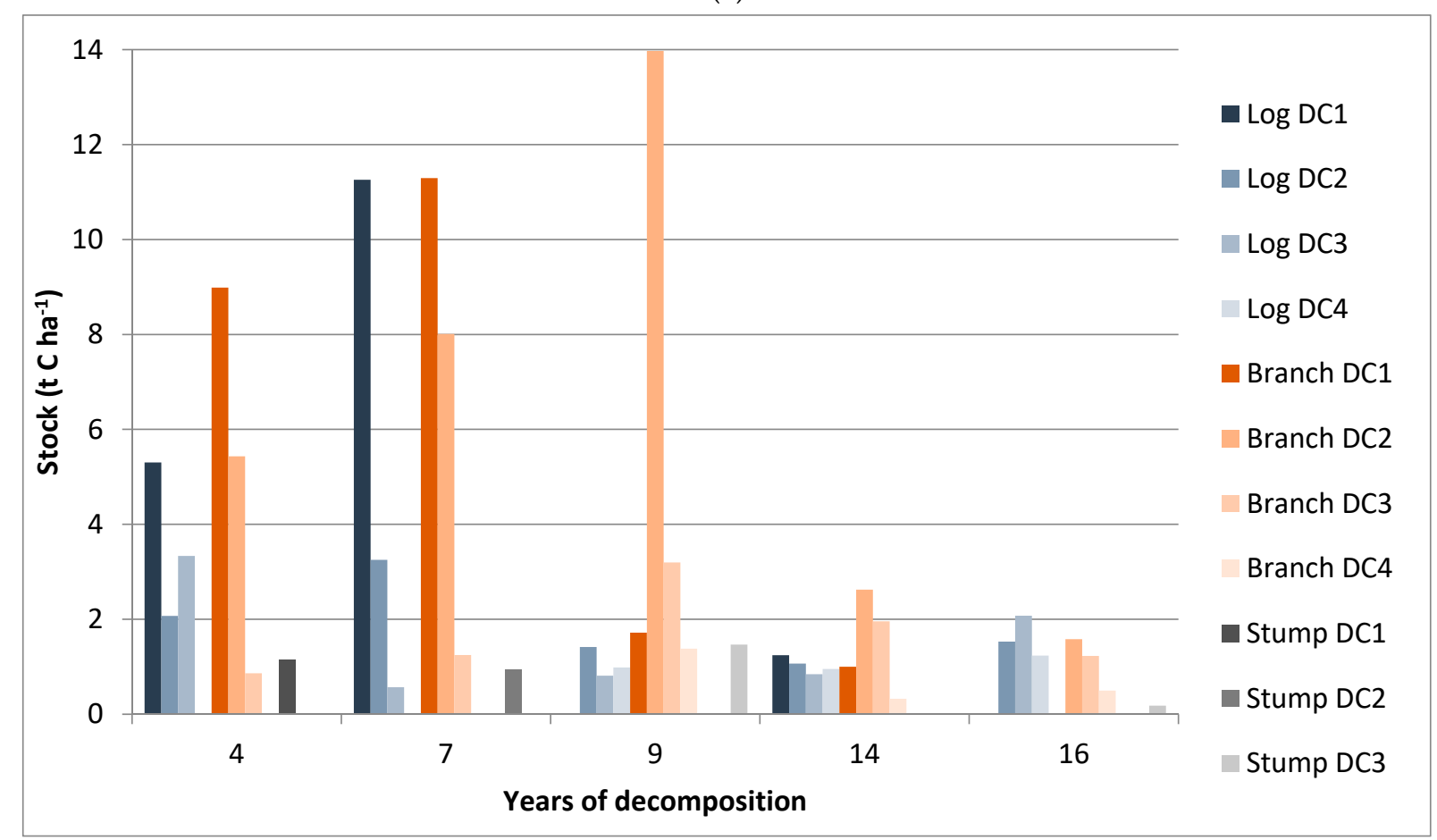

(b)

Figure 2. (a) C stocks of windrowed woody debris and litter; and (b) C stocks of the stump, branch and log categories, per decay class (DC). 


\subsection{WD Density}

The measured density of each WD type at all sites was dependent on the DC assigned $(p<0.05)$. There was a progressive loss in density from DC0 to DC4 in all WD types (Table 4$)$. When criss-cross comparisons were made, the DC density of logs was significantly different to those of branches $(p=0.03)$ but not to those of stumps $(p=1.12)$.

Table 4. Mean densities $\left(\mathrm{g} \mathrm{cm}^{-3}\right.$ ) with associated standard error (S.E.) (in italics) and sample sizes ( $\mathrm{n}$ ) for $\log$, branch, and stump samples by DC. The parameter $\mathrm{k}$ represents the estimated decomposition rate of windrowed Sitka spruce $\mathrm{WD}$, while $k_{\mathrm{DC}}$ is the DC-based decomposition rate (Equation (3). Half-life (HL) is the time taken (in years) for $50 \%$ of the material to decompose (years). The superscripted letters present the results of analysis of variance (at the $95 \%$ level). Observations with a different letter were significantly different.

\begin{tabular}{|c|c|c|c|c|c|c|c|c|}
\hline $\begin{array}{l}\text { CWD } \\
\text { Type }\end{array}$ & & $k$ & DC0 & DC1 & DC2 & DC3 & DC4 & HL \\
\hline \multirow[t]{4}{*}{ Logs } & Density & 0.037 & $0.42^{\mathrm{a}}$ & $0.39^{a b}$ & $0.35^{b}$ & $0.28^{c}$ & $0.27^{c}$ & 18.7 \\
\hline & $k_{\mathrm{DC}}$ & & & 0.05 & 0.08 & 0.13 & 0.10 & \\
\hline & S.E. & & 0.025 & 0.005 & 0.011 & 0.015 & 0.023 & \\
\hline & $n$ & & 7 & 7 & 19 & 12 & 5 & \\
\hline \multirow[t]{4}{*}{ Branches } & Density & 0.038 & $0.64^{\mathrm{a}}$ & $0.57^{b}$ & $0.52^{c}$ & $0.41^{\mathrm{d}}$ & $0.26^{\mathrm{e}}$ & 18.2 \\
\hline & $k_{\mathrm{DC}}$ & & & 0.11 & 0.10 & 0.15 & 0.22 & \\
\hline & S.E. & & 0.035 & 0.014 & 0.014 & 0.018 & 0.023 & \\
\hline & $n$ & & 9 & 8 & 25 & 24 & 10 & \\
\hline \multirow[t]{4}{*}{ Stumps } & Density & 0.044 & $0.44^{\mathrm{a}}$ & $0.41^{b}$ & $0.39^{b}$ & $0.26^{c}$ & & 15.7 \\
\hline & $k_{\mathrm{DC}}$ & & & 0.06 & 0.05 & 0.16 & & \\
\hline & S.E. & & 0.007 & 0.001 & 0.003 & 0.028 & & \\
\hline & $n$ & & 9 & 6 & 9 & 9 & & \\
\hline
\end{tabular}

The branches had higher DC densities $\left(0.643 \mathrm{~g} \mathrm{~cm}^{-3}\right)$ in the early stages of decay compared to log and stump samples ( 0.417 and $0.438 \mathrm{~g} \mathrm{~cm}^{-3}$, respectively). The overall mean initial density was $0.49 \mathrm{~g} \mathrm{~cm}^{-3}$. Decay class 4 , the most advanced decay class, had an average density for all WD types equal to $0.26 \mathrm{~g} \mathrm{~cm}^{-3}$.

\subsection{Decomposition Rates}

Decay curves were calculated using Equation (2) and describe changes in mean density within each WD category with time (Figure 3). Stumps had the highest decay rate (Table 4; $\mathrm{k}=0.044 \mathrm{~g} \mathrm{~cm}^{-3} \mathrm{yr}^{-1}$ ) while those of logs and branches showed a similar, but lower, trend ( $k=0.037$ and $0.038 \mathrm{~g} \mathrm{~cm}^{-3} \mathrm{yr}^{-1}$, respectively). The $k$ values calculated in this study were not significantly different between the three WD categories; accordingly, it can be concluded, similarly to other studies $[21,36,37]$ that the nature of downed material did not much affect the decomposition rates. The log and stump decay curves produced the best fit $\left(R^{2}=0.52\right.$ and 0.50 , respectively) for the exponential relationship between density and time, while the coefficient of determination for the curve fitted to the branch was lower $\left(R^{2}=0.33\right.$, S.E. $\left.=0.034\right)$ but included a higher degree of variation.

As suggested by Tobin et al. [11], another way to express decomposition rates is to compute separate density decay constants according to the DC system $\left(k_{\mathrm{DC}}\right)$ using Equation (3).

$$
k_{\mathrm{DC}}=\frac{\left(\ln D_{0}-\ln D_{\mathrm{DC}}\right)}{\mathrm{DC}}
$$

where $\ln D_{0}$ is the natural logarithm of the initial density and $\ln D_{\mathrm{DC}}$ the natural logarithm according to the change in DC (decay class). 

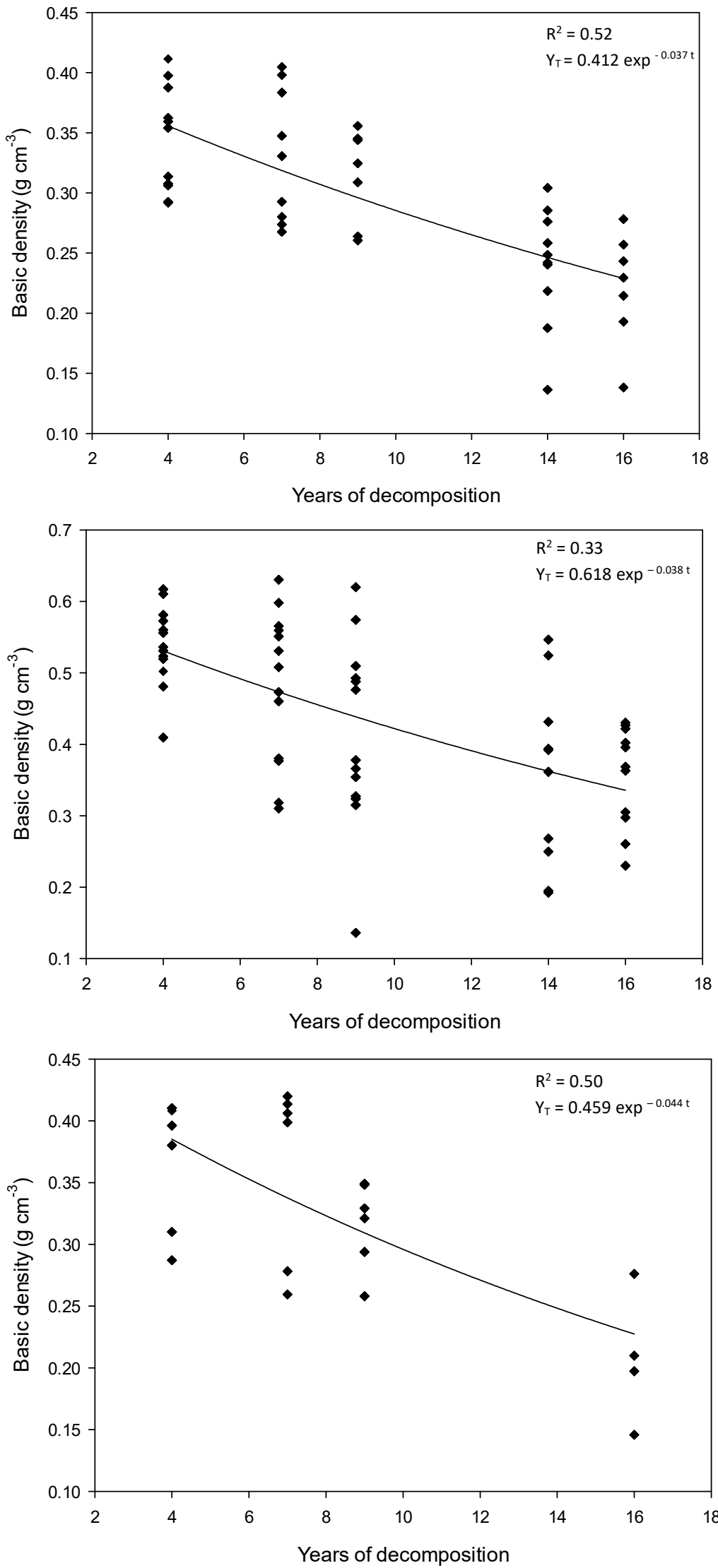

Figure 3. Exponential decay curves describing the decomposition rate of Sitka spruce logs (top), branches (middle), and stumps (bottom) from the relationship between density and time of decay (all equations are significant at $p<0.05$, parameters are described in Table 4 ). 
If forest management records regarding the age of WD are not available, it may be useful to compute the decomposition stages in terms of DC rather than time. Unlike the decay rate constant $k$ (expressed in terms of time), $k_{\mathrm{DC}}$ of branches was approximately $38 \%$ greater than for logs and stumps.

\section{Discussion}

\subsection{Diameter and Decay Class Distribution of Windrowed WD}

The volume of windrowed WD ranged between 98.1 and $50.3 \%$ of all aboveground WD at sites $\mathrm{A}$ to $\mathrm{E}$, respectively. The distribution of WD in different decay and diameter classes also varied considerably among forest stands. It was likely affected by stocking variation in the stands felled at clearfell stages; management records pointed to comparable rotation age and quality. The 14-year-old site contained windrowed material across all decay classes. Material in the $<7$ and $>1 \mathrm{~cm}$ size class (branches) was the main WD component in this coniferous forest type and represented over $44 \%$ of WD mass. The high proportion of branches in WD is similar to findings by Gryc et al. [38] and Weggler et al. [35]. The greatest proportion of total WD mass at all the forest stands (with the exception of site E) was categorized as DCs 1 and 2, echoing findings by Krueger et al. [39]. These two DCs accounted for $84.4 \%$ of WD at site $\mathrm{A}, 94.5 \%$ at site B, $69.4 \%$ at site C, and $29.6 \%$ at site D. However, at site E, DC 3 and 4 accounted for $62.3 \%$ of total WD mass.

\subsection{WD Density and Decomposition Rates}

This study found a decrease in density when moving from decay class DC 0 to 4 of up to $35 \%$ for logs, $59 \%$ for branches, and $40 \%$ for stumps. Patterns in WD density estimates for logs, branches, and stumps were similar to those reported by many other authors (e.g., $[40,41]$. As expected, the progression of decay was not always directly proportional to WD-age; it is not a constant mass loss rate over time, but follows an exponential trend influenced by several processes [16]. Rates of respiration, fragmentation, leaching, as well as substrate quality, invertebrate decomposer activity, and weathering were listed by Mackensen and Bauhus [42], in order of decreasing magnitude, as controlling factors in woody decomposition. In Ireland, high rainfall events and mild winter temperatures result in highly moist soil (and WD) conditions, and this greatly influences the degree of leaching, fragmentation and microbial colonization of WD [30].

The $50 \%$ decomposition values derived in this study (Table 4 ) are comparable to those of other studies [42-44] for a range of forest tree species and the estimated half-life (number of years necessary for the loss of 50\% C mass) for windrowed WD was 18 years for logs and branches and 15 years for stumps. Laliberté et al. [45] suggested that k estimates will be most accurate when mid to late stages of decomposition (50-80\% mass loss) are included in a study and the number of measurements over time is greater than 4 . Accordingly, this indicates that this study covers reasonably the early to middle stages (to approximately $50 \%$ ) of decomposition. However, the latter stages remain poorly described.

The single-exponential model is the most commonly-used function to characterize decomposition rates, but it has been demonstrated that it does not always adequately describe the full extent of the woody decomposition process [23]. However, the exponential decay models parameterized in this study explained between $33 \%$ and $52 \%$ of the variance in WD data. Thus, there remains a significant proportion of unexplained residual variance, suggesting that factors not included in this study also contributed to the wood decomposition rates (e.g., fragmentation; see Bond-Lamberty and Gower [46] and Fraver et al. [23]). The rates for all WD types in this study are comparable with the $\mathrm{k}$ for the rapid phase of decomposition suggested by Yatskov et al. [47] for Picea species ( 0.045 year $\left.^{-1}\right)$. Branch $\mathrm{k}$ values are similar to those mentioned by Gryc et al. [38], while log and stump k values did not differ much when compared with values in other studies like Janisch et al. [36] and Herrmann et al. [5]. Branch $\mathrm{k}$ values were almost $40 \%$ higher than those for logs or stumps. A possible explanation for this discrepancy might follow differences in basic density (Figure 3) as well as arise from differences in the breakdown of wood material 
resulting from variations in intrinsic composition (e.g., higher vs. lower lignin content), though this was not possible to measure in this study.

\subsection{Carbon Stocks/Losses and Effects of Windrowing}

The results revealed that $C$ storage in deadwood varied depending on the developmental stage of the forest, with the largest amount of $C$ stored in the very early stage of breakdown (Table 3). This stage was represented by the two youngest sites which contained much greater $\mathrm{C}$ stocks in deadwood than at other stages. The variation in stocks in the first two chronosequence stages likely resulted from variations in the forest stocking rate at the time of clearfell. Stand deadwood $C$ stocks declined with debris age (years since clearfelling). Unsurprisingly, WD material at the oldest site in the latter DCs were almost double those stocks earlier in the chronosequence. According to this study, and confirmed by Kolari et al. [48], WD stocks are more significant in the earlier stages of forest development because of the great mass of stumps and CWD following thinning and clearcut operations. The windrowed $\mathrm{C}$ stock resulting from harvest residue accumulating on-site ranged between $9.82 \mathrm{t} \mathrm{C} \mathrm{ha}^{-1}$ (16-yr-old site) and $42.46 \mathrm{t} \mathrm{C} \mathrm{ha}^{-1}$ (7-yr-old site). It has been reported also that aboveground WD stocks decrease markedly with the intensity of forest management, mainly because of increasing removals of potential deadwood material leaving less to decompose on the forest floor [2,39]. Consequently, the importance of $C$ losses from windrowed WD plays a central role for nutritional capital, especially in mature forests.

Annual losses from the youngest site were high (Table 3), while losses from older stands (14 and 16 years old) were in accordance with losses reported in other studies [11]. To examine the potential impact of windrows on stand growth, the height and diameter of sampling plot trees beside windrows and furthest away were compared. Although there was no difference in height, there was a statistically significance difference in diameter at all sites apart from A (pers comm., Paul Collins). Though windrows offer shelter to younger trees during early development, the continued difference in growth particularly at the latter stages of the chronosequence points to an enhanced nutritional effect [49].

One of the research questions concerned the degree to which decomposition of WD varied between open, clearfelled, and reforested (windrowed) stands and less open, preclearfell (not windrowed) stands, assuming generally similar climatic conditions. A comparison with Olajuyigbe et al. [30] indicates higher decomposition rates for WD under forest canopies than in open stands. As indicated by Harmon et al. [21], the enhanced moisture content with less opportunity for drying and warming by solar radiation can contribute to hastening decomposition rates. Moreover, the rate of decomposition of stumps found within windrows was enhanced compared to that of non-windrowed ones, though this is not surprising as the process of windrowing will have resulted in significant physical damage in comparison to those remaining in the soil. To better understand the extent of such differences, there is a need to include the whole spectrum of woody debris under different environmental conditions and management intensities in a single study. However, apart from the stumps and roots (which make up a small proportion of windrows), the protection of other WD components from physical disturbance afforded by windrows likely slowed the decomposition rate which will extend the period of $C$ retention, in addition to maintaining nutritional capital within a stand for longer.

\subsection{Drivers of Carbon and Nutrient Release from Windrow Decomposition}

The few studies assessing the effects of harvesting operations on solute leaching from WD vary both in magnitude and results. It is well known that harvesting generally increases soil temperatures (driving higher decomposition rates which tend to increase dissolved organic carbon (DOC) leaching [21,50], but also reduces redox status (through higher water tables, which tend to lower rates of DOC leaching [51,52]). Soil and windrow $\mathrm{CO}_{2}$ emission rates were quantified by Pastore et al. [29] using a portable system (LI-6400 $\mathrm{XT}$ ) in a subset of the chronosequence sites. Soil temperature was found to be a strong 
driver of both soil and windrow effluxes in this temperate forest site and explained most of the seasonal variability of $\mathrm{CO}_{2}$ fluxes. Windrow respiration was approximately 7 times higher than the background soil $\mathrm{CO}_{2}$ efflux, and in all cases the highest emission was recorded early in the summer and the lowest in January. The effect of soil moisture on windrow respiration was less important than temperature but not negligible. De facto it was observed, as in many other studies, that soil moisture was inversely correlated to both soil and windrow respiration. Accordingly, it has also been suggested that increases in DOC and dissolved organic nitrogen (DON) transport would result from (climatechange-induced) increases in temperature [50,53]; however, results from this study did not find temperature to be a significant factor controlling solute leaching. In terms of future predictions, if the climate change scenario becomes dryer, soil $\mathrm{CO}_{2}$ respiration (at least the heterogeneous element derived from WD decay) will experience a net increase, whereas an increase in wet summers is likely to affect soil $\mathrm{CO}_{2}$ effluxes to a lesser extent.

The lack of correlation with temperature indicates that the release of dissolved organic forms of $\mathrm{C}$ and $\mathrm{N}$ might not be directly controlled by the activity of decomposers, and some studies have indicated that decreases in atmospheric deposition of sulphur $(\mathrm{S})$ may be the cause of the observed DOC increases [54]. In the series of sites considered by this study, WD leached high concentrations of DOC to the underlying soil, and this leaching has the potential to be an important, small-scale flux, in accordance with findings by Hentschel et al. [24]. The range of DOC concentrations found in runoff from the windrowed debris in this study was comparable to the range observed in several other studies $[55,56]$. The annual average DOC concentrations were approximately 6 to 12 times higher than in throughfall, emphasizing the role WD (particularly when concentrated spatially into windrows) plays as hotspots for DOC inputs to forest soils, even in the early stages of decomposition. In general terms, DOC release from WD might be expected to increase with decomposition stage, but-surprisingly-results showed the opposite trend (Table 5). The reasons for intra-specific variations remain uncertain and speculative; the nature of the debris is itself highly variable, thus high variation in leaching should be expected; moreover, variations of wood chemical composition with time, as well as small scale heterogeneity of throughfall inputs at the forest stands might all contribute.

Table 5. Annual windrow carbon losses estimated from changes in WD density over time (this study) are compared to alternative estimates derived from two pathways, leaching and respiration (from Pastore et al. [29]). All estimates were based on measurements at the same sampling locations. C losses were calculated by scaling windrow rates to stand level, assuming that windrows covered approximately $7 \%$ of a site's area. Respiration was not assessed at sites B and C because of practical considerations.

\begin{tabular}{|c|c|c|c|c|}
\hline Sample Site & $\begin{array}{c}\text { Age since } \\
\text { Clearfell } \\
\text { (years) }\end{array}$ & $\begin{array}{c}\text { Density Loss } \\
\left(\mathrm{kg} \mathrm{C} \mathrm{ha}^{-1}\right. \\
\left.\mathrm{yr}^{-1}\right)\end{array}$ & $\begin{array}{c}\text { Leached C } \\
\left(\mathrm{kg} \mathrm{C} \mathrm{ha}^{-1}\right. \\
\left.\mathrm{yr}^{-1}\right)\end{array}$ & $\begin{array}{c}\text { Respired C } \\
\left(\mathrm{kg} \mathrm{C} \mathrm{ha}^{-1}\right. \\
\left.\mathrm{yr}^{-1}\right)\end{array}$ \\
\hline Site A & 4 & 5150.42 & 77.02 & $11,710.03$ \\
\hline Site B & 7 & 3020.18 & 67.16 & - \\
\hline Site C & 9 & 4220.57 & 90.24 & $16,130.31$ \\
\hline Site D & 14 & 1130.71 & 76.48 & - \\
\hline Site E & 16 & 680.31 & 33.37 & 8310.47 \\
\hline
\end{tabular}

Differences in flow paths of water along the windrowed logs and other material also add spatial variability to the DOC release. Rates of net DOC and TDN release from windrowed debris were strongly related to monthly and annual precipitation amounts. This agrees with findings from other studies of temperate forest percolates [57-59]. Pastore et al. [29] found strong relationships between $\mathrm{DOC}$, dissolved inorganic $\mathrm{C}$, and total dissolved $\mathrm{N}$ net release and precipitation/throughfall amounts. Magnússon et al. [28] suggest that such inputs from WD may be extremely important for the stabilization of soil C stocks. The patterns of $\mathrm{N}$ loss at Ballinastoe demonstrated that even recently created WD has the potential to leach comparatively large quantities of $\mathrm{N}$. It is important to realize that this result does not mean that a net accumulation of $\mathrm{N}$ is not occurring in such WD, but, on the contrary, 
findings from this study support the hypothesis that WD acts as a sink for mineral $\mathrm{N}$ from throughfall in the early phase of decomposition. This process contributes to the ecological role of woody debris in the retention of $\mathrm{N}$ in forest sites (in addition to other nutrients, e.g., phosphorus (P), S, calcium) for several decades [8,29].

\subsection{Contribution of Fragmentation to Woody Decomposition}

Fragmentation is often presumed to be an important aspect of woody decomposition; however, because of the inherent difficulties involved in its quantification, very few studies have estimated the proportional contribution [21]. In this study, the discrepancies between the two methodologies employed (carbon loss estimates via leaching and respiration versus density loss) are attributed mainly to the missing effect of fragmentation rates. The estimates based on respiration and leaching were derived by scaling-up point emission measurements, whereas the estimates based on density loss involved a qualification of the stock quality observed at a specific point (Table 5). Both methodologies depend on slightly different assumptions, but the largest process unaccounted for is likely to be the combined effect of fragmentation and weathering. Based on this assumption, the contribution of fragmentation to $C$ loss across the chronosequence was $56 \%, 74 \%$, and $92 \%$ at sites A, C, and E, respectively. It is likely that the process of windrowing contributed to this through the physical compression and breakage of WD material in addition to the increased attractiveness of the concentrated location supporting greater invertebrate biodiversity and activity [23].

Mattson et al. [60] and Chueng and Brown [61] suggested that fragmentation and leaching together accounted for a small proportion (about 10 to 34\%) of total C mass loss, though both studies focused on mixed hardwood forests. However, Harmon et al. [21] indicated that woody fragmentation may contribute considerably to annual mass loss (up to $63 \%$;). It is likely that fragmentation plays a particularly large role in the decomposition of coniferous WD, particularly in warm, moist (but not inundated) temperate forest types, such as those represented in this study.

\section{Conclusions}

This study highlights the significant impact of WD on C budgets (and their potential management) in highly productive Sitka spruce commercial forests, the most common forest ecosystem type in Ireland. Windrowed WD in reforested Sitka spruce stands represents a spatially patterned network of "hotspots" of $\mathrm{C}$ accumulation, $\mathrm{CO}_{2}$ respiration directly to the atmosphere, and the net release of DOC and N, providing substantial $\mathrm{C}$ and $\mathrm{N}$ inputs into the soil (or ground water) beneath the WD. As shown in Table 5, this conclusion was reached using a combination of two approaches: 1 . leaching + respiration, and 2. density loss. The decomposition calculated from the sum of leaching and respiration was almost 2.27 times higher than the estimate based on density loss at the younger stand. This rose to almost 12 times higher at the oldest stand. Although there has been relatively little research on this topic, leaching can be considered an important process in WD decomposition [21], but in this study it constituted a very minor proportion of $C$ losses. Future research might consider a combined sampling of WD runoff and soil solution beneath WD to determine the fate of WD-derived dissolved organic C and $\mathrm{N}$.

The forest development stage (open stands: sites A, B, and C-vs. closed stands: sites D and E) influenced the DOC and total N net release from WD in a significant way, though the windrowing operation probably ensured the storage effect of $\mathrm{C}$ and $\mathrm{N}$ was prolonged (compared to where WD is left more spatially distributed) by protecting it from physical disturbance and breakdown. In forest systems with nutrient-poor soils, falling trees can deliver a large pulse of nutrients above- and belowground, especially after major disturbances. By contrast, the relatively slow decomposition of windrowed WD results in the gradual release of nutrients that are subsequently incorporated into the forest floor and humus over time, providing a valuable resource to the stand and ecosystem contributing to sustainable yield. This means that windrowing could store $C$ and other 
nutrients (in particular $\mathrm{N}$ ) for an extended period and partially offset disturbance-related soil $\mathrm{C}$ losses. In a changing climate scenario, potential increases in WD decomposition rates may result in more rapid release of nutrients, increasing nutrient availability in early stages of regeneration but reducing availability later.

Author Contributions: All three authors collaborated closely on this study. Specifically, contributions were as follows. Conceptualization, B.T. and M.N.; methodology, B.T.; formal analysis, G.P.; investigation, G.P., B.T. and M.N.; writing-original draft preparation, G.P.; writing-review and editing, B.T., G.P. and M.N.; supervision, B.T. and M.N.; project administration, B.T.; funding acquisition, B.T. and M.N. All authors have read and agreed to the published version of the manuscript.

Funding: This research was funded by the Irish Department of Agriculture, Food and the Marine under COFORD as part of the Carbon Sequestration in Irish Forest Ecosystems (CForRep project; $11 / \mathrm{C} / 205)$.

Institutional Review Board Statement: Not applicable.

Informed Consent Statement: Not applicable.

Data Availability Statement: Not applicable.

Acknowledgments: Coillte provided access to and management records for the forest stands used in the sampling. The authors are grateful for assistance rendered by Antonio Cachinero Vivar, Alice Rafa, Conor Coatney, Helene Toutain, and Paul Denailly for field data collection and lab measurements. Thomas Turpin-Jelfs assisted with initial experimental set-up and measurements. Paul Collins supplied the stand inventory data. The improvements to the manuscript resulting from the constructive comments of two anonymous reviewers are much appreciated.

Conflicts of Interest: The authors declare no conflict of interest.

\section{References}

1. Harmon, M.E.; Hua, C. Coarse woody debris dynamics in two old-growth ecosystems. Bioscience 1991, 4, 604-610. [CrossRef]

2. Zhou, L.; Dai, L.; Gu, H.; Zhong, L. Review on the decomposition and influence factors of coarse woody debris in forest ecosystem. J. For. Res. 2007, 18, 48-54. [CrossRef]

3. Kahl, T.; Baber, K.; Otto, P.; Wirth, C.; Bauhus, J. Drivers of $\mathrm{CO}_{2}$ emission rates from dead wood logs of 13 tree species in the initial decomposition phase. Forests 2015, 6, 2484-2504. [CrossRef]

4. Kruys, N.; Jonsson, B.G.; Ståhl, G. A stage-based matrix model for decay-class dynamics of woody debris. Ecol. Appl. 2002, 12, 773-781. [CrossRef]

5. Herrmann, S.; Kahl, T.; Bauhus, J. Decomposition dynamics of coarse woody debris of three important central European tree species. For. Ecosyst. 2015, 2, 27. [CrossRef]

6. Caza, C.L. Woody Debris in the Forests of British Columbia: A Review of the Literature and Current Research; B.C. Ministry of Forests Land Management Report No. 78; Ministry of Forests: Victoria, BC, Canada, 1993; p. 99.

7. Johnson, D.W.; Curtis, P.S. Effects of forest management on soil carbon and nitrogen storage: Meta-analysis. For. Ecol. Manag. 2001, 140, 227-238. [CrossRef]

8. Herrmann, S.; Bauhus, J. Nutrient retention and release in coarse woody debris of three important central European tree species and the use of NIRS to determine deadwood chemical properties. For. Ecosyst. 2018, 5, 22. [CrossRef]

9. Currie, W.S.; Nadelhoffer, K.J. The Imprint of Land-use History: Patterns of Carbon and Nitrogen in Downed Woody Debris at the Harvard Forest. Ecosystems 2002, 5, 446-460. [CrossRef]

10. Jomura, M.; Kominami, Y.; Tamai, K.; Miyama, T.; Goto, Y.; Dannoura, M.; Kanazawa, Y. The carbon budget of coarse woody debris in a temperate broad-leaved secondary forest in Japan. Tellus B 2007, 59, 211-222. [CrossRef]

11. Tobin, B.; Black, K.; McGurdy, L.; Nieuwenhuis, M. Estimates of decay rates of components of coarse woody debris in thinned Sitka spruce forests. Forestry 2007, 80, 455-469. [CrossRef]

12. Vítková, L.; Bače, R.; Kjučukov, P.; Svoboda, M. Deadwood management in Central European forests: Key considerations for practical implementation. For. Ecol. Manag. 2018, 429, 394-405. [CrossRef]

13. Stevens, V. The Ecological Role of Coarse Woody Debris: An Overview of the Ecological Importance of CWD in B.C. Forests; Working Paper 30; British Columbia, Ministry of Forests, Research Program: Victoria, BC, Canada, 1997.

14. Di Cosmo, L.; Gasparini, P.; Paletto, A.; Nocetti, M. Deadwood basic density values for national-level carbon stock estimates in Italy. For. Ecol. Manag. 2013, 295, 51-58. [CrossRef]

15. Harmon, M.; Franklin, J.; Swanson, F.; Sollins, P.; Gregory, S.; Lattin, J.; Anderson, N.; Cline, S.; Aumen, N.; Sedell, J.; et al. Ecology of coarse dead wood in Temperate Ecosystems. Adv. Ecol. Res. 1986, 15, 133-302. 
16. Woldendorp, G.; Keenan, R.J. Coarse woody debris in Australian forest ecosystems: A review. Austral. Ecol. 2005, 30, 834-843. [CrossRef]

17. Nakamura, F.; Swanson, F.J. Effects of coarse woody debris on morphology and sediment storage of a mountain stream system in western Oregon. Earth Surf. Process. Landf. 1993, 18, 43-61. [CrossRef]

18. Woodall, C.W.; Heath, L.S.; Smith, J.E. National inventories of down and dead woody material forest carbon stocks in the United States: Challenges and opportunities. For. Ecol. Manag. 2008, 256, 221-228. [CrossRef]

19. Bradford, J.; Weishampel, P.; Smith, M.-L.; Kolka, R.; Birdsey, R.A.; Ollinger, S.V.; Ryan, M.G. Detrital carbon pools in temperate forests: Magnitude and potential for landscape-scale assessment. Can. J. For. Res. 2009, 39, 802-813. [CrossRef]

20. Zell, J.; Kandler, G.; Hanewinkel, M. Predicting constant decay rates of coarse woody debris-A meta-analysis approach with a mixed model. Ecol. Model. 2009, 220, 904-912. [CrossRef]

21. Harmon, M.E.; Fasth, B.G.; Yatskov, M.; Kastendick, D.; Rock, J.; Woodall, C.W. Release of coarse woody detritus-related carbon: A synthesis across forest biomes. Carbon Balance Manag. 2020, 15, 1. [CrossRef] [PubMed]

22. Fasth, B.G.; Harmon, M.E.; Sexton, J.; White, P. Decomposition of fine woody debris in a deciduous forest in North Carolina. J. Torrey Bot. Soc. 2011, 138, 192-206. [CrossRef]

23. Fraver, S.; Milo, A.M.; Bradford, J.B.; D'Amato, A.W.; Kenefic, L.; Palik, B.J.; Woodall, C.W.; Brissette, J. Woody Debris Volume Depletion Through Decay: Implications for Biomass and Carbon Accounting. Ecosystems 2013, 16, 1262-1272. [CrossRef]

24. Hentschel, K.; Borken, W.; Matzner, E. Leaching losses of inorganic N and DOC following repeated drying and wetting of a spruce forest soil. Plant Soil 2007, 300, 21-34. [CrossRef]

25. Stokland, J.N.; Siitonen, J.; Jonsson, B.G. Biodiversity in Dead Wood. Cambridge University Press: Cambridge, UK, 2012.

26. McMinn, J.W.; Crossley, D.A., Jr. Biodiversity and Coarse Woody Debris in Southern Forests; Report: SE-94; USDA Forest Service: Asheville, North Carolina, 1993.

27. Grove, S.J.; Stamm, L.; Barry, C. Log decomposition rates in Tasmanian Eucalyptus oblique determined using an indirect chronosequence approach. For. Ecol. Manag. 2009, 258, 389-397. [CrossRef]

28. Magnússon, R.Í.; Tietema, A.; Cornelissen, J.H.C.; Hefting, M.M.; Kalbitz, K. Tamm Review: Sequestration of carbon from coarse woody debris in forest soils. For. Ecol. Manag. 2016, 377, 1-15. [CrossRef]

29. Pastore, G.; Tobin, B.; Nieuwenhuis, M. Quantifying carbon and nitrogen losses by respiration and leaching from decomposing woody debris in reforested coniferous stands in Ireland. Agric. For. Meteorol. 2019, 265, 195-207. [CrossRef]

30. Olajuyigbe, S.O.; Tobin, B.; Gardiner, P.; Nieuwenhuis, M. Stocks and decay dynamics of above- and belowground coarse woody debris in managed Sitka spruce forests in Ireland. For. Ecol. Manag. 2011, 262, 1109-1118. [CrossRef]

31. Arthur, M.A.; Fahey, T.J. Biomass and nutrients in an Engelmann spruce-subalpine fir forest in north central Colorado: Pools, annual production, and internal cycling. Can. J. For. Res. 1992, 22, 315-325. [CrossRef]

32. Petrillo, M.; Cherubini, P.; Sartori, G.; Abiven, S.; Ascher, J.; Bertoldi, D.; Camin, F.; Barbero, A.; Larcher, R.; Egli, M. Decomposition of Norway spruce and European larch coarse woody debris (CWD) in relation to different elevation and exposure in an Alpine setting. iForest 2015, 9, 154. [CrossRef]

33. Olesen, P.O. The water displacement method. A fast and accurate method of determining the green volume of wood samples. For. Tree Improv. 1971, 3, 1-23.

34. Chave, J. Measuring Wood Density for Tropical Forest Trees. A Field Manual for the CTFS Sites. Wood Density Measurement Protocol. 2005, pp. 1-7. Available online: http://chave.ups-tlse.fr/chave/wood-density-protocol.pdf (accessed on 21 September 2020).

35. Weggler, K.; Dobbertin, M.; Jüngling, E.; Kaufmann, E.; Thürig, E. Dead wood volume to dead wood carbon: The issue of conversion factors. Eur. J. For. Res. 2015, 131, 1423-1438. [CrossRef]

36. Janisch, J.E.; Harmon, M.E.; Chen, H.; Fasth, B.; Sexton, J. Decomposition of coarse woody debris originating by clearcutting of an old-growth conifer forest. Ecoscience 2005, 12, 151-160. [CrossRef]

37. Shorohova, E.; Kapitsa, E. Influence of the substrate and ecosystem attributes on the decomposition rates of coarse woody debris in European boreal forests. For. Ecol. Manag. 2014, 315, 173-184. [CrossRef]

38. Gryc, V.; Vavrčík, H.; Šlezingerová, J.; Koňas, P. Basic density of spruce wood, wood with bark, and bark of branches in locations in the Czech Republic. In TRACE-Tree Rings in Archaeology, Climatology and Ecology; Scientific Technical Report Potsdam; GFZ Potsdam: Potsdam, Germany, 2010; Volume 8, pp. 151-156.

39. Krueger, I.; Schulz, C.; Borken, W. Stocks and dynamics of soil organic carbon and coarse woody debris in three managed and unmanaged temperate forests. Eur. J. For. Res. 2017, 136, 123-137. [CrossRef]

40. Stone, J.N.; MacKinnon, A.; Parminter, J.V.; Lertzman, K.P. Coarse woody debris decomposition documented over 65 years on southern Vancouver Island. Can. J. For. Res. 1998, 28, 788-793. [CrossRef]

41. Rock, J.; Badeck, F.-W.; Harmon, M.E. Estimating decomposition rate constants for European tree species from literature sources Eur. J. For. Res. 2008, 127, 301-313. [CrossRef]

42. Mackensen, J.; Bauhus, J. Density loss and respiration rates of coarse woody debris of Pinus radiata, Eucalyptus regnans and Eucalyptus maculata. Soil Biol. Biochem. 2003, 35, 177-186. [CrossRef]

43. Herault, B.; Beauchene, J.; Muller, F.; Wagner, F.; Baraloto, C.; Blanc, L.; Martin, J.-M. Modeling decay rates of dead wood in a neotropical forest. Oecologia 2010, 164, 243-251. [CrossRef] [PubMed] 
44. Freschet, G.T.; Aerts, R.; Cornelissen, J.H.C. A plant economics spectrum of litter decomposability. Funct. Ecol. 2012, $26,56-65$. [CrossRef]

45. Laliberté, E.; Adair, E.C.; Hobbie, S.E. Estimating litter decomposition rate in single-pool models using nonlinear beta regression. PLOS ONE 2012, 7, e45140. [CrossRef]

46. Bond-Lamberty, B.; Gower, S.T. Decomposition and Fragmentation of Coarse Woody Debris: Re-visiting a Boreal Black Spruce Chronosequence. Ecosystems 2008, 11, 831-840. [CrossRef]

47. Yatskov, M.; Harmon, M.E.; Krankina, O.N. A chronosequence of wood decomposition in the boreal forests of Russia. Can. J. For. Res. 2003, 33, 1211-1226. [CrossRef]

48. Kolari, P.; Pumpanen, J.; Rannik, U.; Ilvesniemi, H.; Hari, P.; Berninger, F. Carbon balance of different aged Scots pine forests in southern Finland. Glob. Chang. Biol. 2004, 10, 1106-1119. [CrossRef]

49. Lasota, J.; Błońska, E.; Piaszczyk, W.; Wiecheć, M. How the deadwood of different tree species in various stages of decomposition affected nutrient dynamics? J. Soils Sediments 2018, 18, 2759-2769. [CrossRef]

50. Laudon, H.; Hedtjärn, J.; Schelker, J.; Bishop, K.; Sørensen, R.; Ågren, A. Response of Dissolved Organic Carbon following Forest Harvesting in a Boreal Forest. Ambio 2009, 38, 381-386. [CrossRef]

51. Tate, C.M.; Meyer, J.L. The influence of hydrologic conditions and successional state on dissolved organic carbon export from forested watersheds. Ecology 1983, 64, 25-32. [CrossRef]

52. Michalzik, B.; Kalbitz, K.; Park, J.H.; Solinger, S.; Matzner, E. Fluxes and concentrations of dissolved organic carbon and nitrogen: A synthesis for temperate forests. Biogeochemistry 2001, 52, 173-205. [CrossRef]

53. Freeman, C.; Ostle, N.J.; Kang, H. An enzymic 'latch' on a global carbon store. Nature 2001, 409, 149. [CrossRef]

54. Ledesma, J.L.J.; Futter, M.N.; Laudon, H.; Evans, C.D.; Köhler, S.J. Boreal forest riparian zones regulate stream sulfate and dissolved organic carbon. Sci. Total Environ. 2016, 560, 110-122. [CrossRef]

55. Hafner, S.D.; Groffman, P.M.; Mitchell, M.J. Leaching of dissolved organic carbon, dissolved organic nitrogen, and other solutes from coarse woody debris and litter in a mixed forest in New York State. Biogeochemistry 2005, 74, 257-282. [CrossRef]

56. Kuehne, C.; Donath, C.; Müller-Using, S.; Bartsch, N. Nutrient fluxes via leaching from coarse woody debris in a Fagus sylvatica forest in the Solling Mountains, Germany. Can. J. For. Res. 2008, 38, 2405-2413. [CrossRef]

57. Michalzik, B.; Matzner, E. Fluxes and dynamics of dissolved organic nitrogen and carbon in a spruce (Picea abies Karst.) forest ecosystem. Eur. J. Soil Sci. 1999, 50, 579-590. [CrossRef]

58. Kaiser, K.; Kaupenjohann, M.; Zech, W. Sorption of dissolved organic carbon in soils: Effects of soil sample storage, soil-to-solution ratio, and temperature. Geoderma 2001, 99, 317-328. [CrossRef]

59. Volk, C.; Wood, L.; Johnson, B.; Robinson, J.; Zhu, H.W.; Kaplan, L. Monitoring dissolved organic carbon in surface and drinking waters. J. Environ. Monit. 2002, 4, 43-47. [CrossRef]

60. Mattson, K.G.; Swank, W.T.; Waide, J.B. Decomposition of woody debris in a regenerating, clear-cut forest in the Southern Appalachians. Can. J. For. Res. 1987, 17, 712-721. [CrossRef]

61. Chueng, N.; Brown, S. Decomposition of silver maple (Acer saccharinum L) woody debris in a central Illinois bottomland forest. Wetlands 1995, 15, 232-241. [CrossRef] 